with ammonia, the aluminium being obtained in alkaline solution. Other metals which are liable to be present have been proved not to interfere. The actual determination is carried out on an aliquot portion containing 0.01-0.06 mgm. of aluminium. Using $20 \mathrm{gm}$. of sample, so little as 0.2 part per million of aluminium can be determined.

The results obtained indicate that the aluminium content of foodstuffs is increased by only a few parts per million after cooking in aluminium utensils. For example, the aluminium content of milk was increased from 0.4 to 0.6 part per million after boiling in an aluminium saucepan, and to $2 \cdot 5$ parts per million after standing overnight. Apples before cooking contained 2 parts per million of aluminium, and after boiling in an aluminium vessel for thirty minutes with sugar and water they contained 14 parts.

Mr. P. L. Bilham described a spectrographic method for the determination of small quantities of aluminium. The aluminium of a biological material is concentrated on to a special electrode. The spectrum is then excited by a condensed spark discharge, modified to remove air-lines as much as possible, and a quartz spectrograph is employed to photograph the spectrum. The plate is developed under standard conditions and then compared with sets of standards on plates prepared under precisely similar conditions. The results show that aluminium is detectable down to $0.01 \mathrm{mgm}$., and that the intensities of the lines at $3944 \mathrm{~A}$. and $3961.5 \mathrm{~A}$. can be used to judge the amount present up to $0.2 \mathrm{mgm}$. The method is, of course, specific for aluminium and of a reasonable accuracy.

\section{Carnegie Grants for Libraries and Museums}

rTHE eighteenth annual report of the Carnegie 1 United Kingdom Trust, for the year ended Dec. 31,1931 , has recently been issued.* The opening paragraphs reflect the influences of the financial position of the country upon policy, inasmuch as the main object of the trustees in the immediate future will be one of consolidation rather than the inauguration of new and pioneer schemes. In their view, the urgent demand for drastic economy in national and local expenditure, coupled with the restriction of private generosity, compels limitations of policy. Grants from the Trust will be made in order to maintain and stabilise activities which have already been assisted and have themselves tended to move forward under their own momentum. But grants for entirely new purposes are to be few in number, and to be made only for exceptionally strong and urgent reasons. These decisions, however prudent, must inevitably bring disappointment in various quarters, but, at any rate, they cannot fail to be understood.

Though most people are aware how wide the net is cast, it may be useful and opportune at this juncture of affairs to recall some of the more important schemes which have received allocation of revenue. Outstanding among these is the acquisition of freehold property in Bloomsbury, intended to form the headquarters of the National Central Library and of the Library Association, in an area contiguous to and ultimately destined for occupation by the new buildings of the University of London. The total sum contemplated for this undertaking is large, amounting in fact to about $£ 60,000$. It is believed that the two institutions, housed as neighbours, will play an essential part in completing the unification of the nation's library service. For the first time in its history the

* The Carnegie United Kingdom FTrust. Eighteenth Annual Report (for the year ending December 31, 1931), approved by the Trustees on March 11, 1932. Pp. ii $+95+4$ plates. (Dunfermline.)
Library Association will be in possession of premises of its own, large enough for practical operations, and consistent with its dignity as a national body established by Royal Charter. It is hoped that the quarters will be ready within about eighteen months. Complementary in interest is the information that the trustees are still prepared to receive applications on behalf of municipal libraries serving populations between 10,000 and 70,000. Aid is given for book. purchase only, and will be made to such authorities as are prepared to carry out, as fully as financial conditions permit, the main principles of approved modern practice.

Substantial grants have been allotted to various research associations and societies-among these we note British Non-Ferrous Metals, Wool Industries, Linen Industry, British Rubber Manufacturers, British Flour Millers, London School of Economics, Entomological Society, Society for Psychical Research. Rural and Social Service includes schemes affecting community centres, boys' and girls' clubs, youth hostels, and village halls. Enterprises relating to activities in the departments of music and drama have received attention; while the sympathy and support extended to rural preservation schemes and playing fields is a record of much interest.

The trustees' 'museum policy', initiated rather more than two years ago, is still in the experimental stage, and there may be a temporary period of inaction. Thirteen centres had accepted or been offered grants up to the end of 1931 for reconstruction purposes. These grants are conditional upon the adoption of a scheme prepared by an expert appointed by a joint committee of the Trust and the Museums Association. The substitution of modern cases, the disposal of miscellaneous and irrelevant material, adequate display and labelling, coupled with the adoption of a progressive policy on the lines recommended in Sir Henry Miers's report, are essential considerations.

Finally, the remarkable development of county libraries, closely fostered by the Library Association, established in local areas, demands a few words. Throughout Britain generally the story is one of judicious expansion. At the end of the year 1930-31, some sixteen millions of the population of the United Kingdom were served through 14,000 library centres, almost all of which were administered by voluntary librarians and enlisted voluntary helpers. In no other country as yet could it be stated that any village librarian, in addition to his periodic supply of anything from 50 to 2000 books, can obtain for borrowers access not only to the county stock of, say, 50,000 150,000 volumes, but also through the county headquarters to nearly $5,000,000$ volumes held or procurable by the National Central Library, and that, as a rule, special books may be sent by post for private study.

\section{University and Educational Intelligence}

CAMBrIDGE.-The governing body of King's College, having made provision for four additional fellowships open for competition to graduate members and research students of the University, is offering a fellowship to be associated with the name of the late Mr. E. B. Stringer. Candidates must be members of the University, less than thirty years of age on March 1, 1933, who have worked in (i) chemistry, (ii) experimental physics, or (iii) the chemistry or physiology of plant or animal life. Applications should reach the Provost by Nov. 1 .

Dubuin.-At a meeting of the Senate of the University of Dublin, Trinity College, on June 29,

No. 3271 , VoL. 130] 
honorary degrees were conferred upon the following, among others: M. Eng.-Prof. F. S. Rishworth, professor of civil engineering in University College, Galway. D.Sc.-Prof. R. G. Harrison, professor of biology in the Yale University; and Prof. T. M. Lowry, professor of physical chemistry in the University of Cambridge. LL.D.-Prof. W. R. Scott, Adam Smith professor of political economy in the University of Glasgow.

EDINBURGH.-At the graduation ceremonial on June 30 the honorary degree of Doctor of Laws was conferred upon the following, among others; Prof. C. V. Boys, Mr. H. M. Cadell; Mr. D. M. Greig, conservator of Museum, Royal College of Surgeons, Edinburgh; Dr. R. S. MacDougall, formerly reader and Steven lecturer in agriculture and forest entomology in the University ; Mr. Andrew Mellon, United States ambassador; Prof. A. Robinson, emeritus professor of anatomy in the University ; Sir Archibald Sinclair, Secretary of State for Seotland; and Sir Josiah Stamp.

The following were admitted to the degree of Doctor of Science, titles of theses appearing after the names : Mr. S. C. Devadatta, "The Distribution of Lactate between the Corpuscles and the Plasma in Blood" Dr. Honor B. Fell, " Morphological and Experimental Studies on the Skeletogenesis of the Fowl " ; Mr. D. Finlayson, "Some Physical Problems associated with the Internal Combustion Engine" ; Mr. D. S. MacLagan, "An Ecological Study of the 'Lucerne Flea' (Smynthurus viridis, Linn.)" ; Dr. D. Meksyn, "Electromagnetic Phenomena in the General Theory of Relativity" ; Mr. H. S. Ruse, "Theorems in the Tensor Calculus" ; Dr. R. H. Slater, "Synthesis of Quinoline Compounds of possible Therapeutic Value".

At the close of the ceremony, the Principal, Sir Thomas Holland, referred to two medallions by Emeritus Professor Schlapp, representing Sir Walter Scott and Thomas Carlyle as students, which have been placed in the McEwan Hall. Walter Scott matriculated in the University in 1783, attended classes for three years but failed in Greek, and his father took him away to his own business. Scott returned in 1789, studied in the Faculty of Law and was admitted to the Faculty of Advocates in 1792. At the age of fourteen years, in 1809, Thomas Carlyle trudged from Ecclefechan to the University of Edin. burgh. He seemed to have profited mainly from the teaching of the professor of mathematics, and later in life, just after he had failed to persuade any publisher to accept "Sartor Resartus", he made an unsuccessful attempt to obtain the professorship of astronomy in the University. He was rejected, and that incident probably turned him finally to letters.

LoNDON.- The following doctorates have been conferred : D.Sc. in anthropology on Dr. E. J. Dingwall (University College) for two works entitled "Male Infibulation" and "Artificial Cranial Deformation" (Bale, Sons, and Danielsson, 1931) ; D.Sc. in chemistry on Mr. J. W. Smith (University College) for a thesis entitled "Studies in Intensive Drying and Related Phenomena" (J. Chem. Soc., 1929 and 1931 ; Phil. Mag., 1929); D.Sc. (Engineering) on Mr. H. C. H. Townend (Northampton Polytechnic Institute) for ten contributions to the study of aerodynamics.

ST. AnDREws.--Amongst those who received the honorary degree of LL.D. at the graduation ceremonial on June 28 were Sir James Frazer, author of "The Golden Bough ", Dr. Albert Schweizer, and Prof. L. R. Sutherland, emeritus professor of pathology in the University.

No. 3271, VoL. 130]

\section{Calendar of Geographical Exploration}

\section{July I I, I6I6.-Samuel de Champlain}

Samuel de Champlain, the great French explorer, returned to Quebec, which he had founded in July 1608 , after his third and greatest journey. He set out in 1615 and, travelling down the Ottawa and Mattawa Rivers, Lake Nipissing, and French River, reached Georgian Bay. Thence he proceeded inland and explored Lake Ontario. Champlain's earliest voyages were to the West Indies and Mexico. In 1603 he travelled up the St. Lawrence, and in the following years surveyed the coasts of Nova Scotia, the Bay of Fundy, and the mainland so far as Cape Cod. In 1613 he reached Allumette Island in the Ottawa River, in an endeavour to discover a supposed short route to the ocean via the Ottawa River. Lakes Champlain, Nipissing, and Simcoe were discovered by him, and he made further journeys on Lakes Huron and Ontario, which had been visited a few years earlier by Brulé. Interestingly enough, Champlain contemplated, during a visit to Panama, the project of a ship canal across the isthmus.

\section{July I I, 1897.-First Air Attempt on the North Pole}

S. A. Andrée, a Swedish aeronaut, with two companions and about five tons of supplies, set out in a balloon for the north pole. Heavy guide-ropes drag. ging over the ice were to be used for steering. Andrée had already made successful flights in this way. Rising from Danes Island, Spitsbergen, at 2.30 P.M., the balloon passed out of sight within an hour. A buoy containing a message that at 10 P.M. the balloon was in $82^{\circ} \mathrm{N}$., $25^{\circ} \mathrm{E}$., moving towards the north-east at an altitude of $800 \mathrm{ft}$., was found. But until Aug. 22 , 1930, nothing more was known of the fate of Andrée and his companions. On that date, members of an expedition to White Island found their bodies and their diaries. They had reached $82^{\circ} 56^{\prime} \mathrm{N}$., but had been compelled to return on foot, and had died at Giles Land, White Island, to the east of Spitsbergen.

\section{July I3, I $102 .-$ An Early Pilgrimage to Jerusalem}

Saewulf, or Saewlf, an Anglo-Saxon native of Worcester, a merchant, took ship at the little harbour of Monopoli, near Bari, for his pilgrimage to the Holy Land. The effect of the Crusades was to encourage such pilgrimages, and Saewulf, though not the first to make the journey, was the first who left a narrative of it. His outward journey was made direct from Italy to the Ionian Islands, from Negropont to Rhodes, and thence to Palestine. His record shows the great increase of European influence in the Levant in war, commerce, and pilgrimage; his account of the destruction of pilgrim and trading vessels in Jaffa during a great storm is specially valuable from this point of view. His description of the sites of Hebron is detailed and interesting. Among other places, he visited Nazareth and Cana of Galilee. He embarked on his return journey at Joppa, coasted down past Tyre, Sidon, and Acre, touched at Cyprus, and put in at Rhodes. There he changed to a smaller vessel and later to another, and proceeded through the Dardanelles. The narrative breaks off abruptly at the point when Saewulf was near Constantinople and wished to worship there before returning home. Inevitably, many of Saewulf's historical explanations seem quaint to modern students, but his narrative throws a good deal of light on conditions in his time.

\section{July I3, I909.-Mikkelsen's Voyages}

Ejmar Mikkelsen left Thorshavn in the Hekla, in command of an expedition to explore north-east Greenland. Mikkelsen had, -with Amdrup, explored 